\title{
THE IMPACT OF THE BITUMINOUS COAL COMBUSTION FROM THE THERMOELECTRIC POWER PLANT FROM PAROȘENI ON THE ENVIRONMENT OF JIU VALLEY
}

\author{
MIRCEA REBRIȘOREANU ${ }^{1}$, EUGEN TRAISTĂ ${ }^{1}$, ARONEL MATEI ${ }^{1}$, \\ OVIDIU BARBU ${ }^{2}$, VLAD A. CODREA ${ }^{2}$
}

\begin{abstract}
The Jiu Valley Basin is one of the most important coal mining areas in Romania. Other industries, including a power plant, are also well developed in this area. Therefore, pollution is very high. One of the most polluted environmental compounds is the air. High mountains surround the Jiu Valley, which makes difficult the air refreshing. For this reason, it is very important to discuss the air pollution and especially that produced by dust. Since the industrial companies are concentrated in a small area, it is very difficult to identify and prosecute the polluting one. The present paper aims to identify the sources of air pollution, especially among the mining companies, because the power plant is considered the most important polluting agent in this area.
\end{abstract}

KEY WORDS: Coal combustion; Valea Jiului Basin; pollution.

\section{Introduction}

The aim of the present paper is to analyse the noxious substances produced by the feeding and firing of the Paroșeni plant (abbreviated: TPP), from the following points of view:

- the release of noxious substances in the atmosphere, as well as the release of pollutants within the roast gases resulting from fuel combustion in the hearth;

- pollutant dispersion within emission.

TPP uses Jiu Valley energetic bituminous coal as the main solid fuel and methane gas as firing support.

The burning of fossil fuels results in loading the atmosphere with a combination of gaseous and solid pollutants, of organic and inorganic origin. The most important ones within this combination are acid gases: sulphur dioxide and trioxide, nitrogen oxides, carbon monoxide and dioxide. In addition to these, there are: powders (ash and smoke black) and some volatile organic compounds (carbohydrates - especially methane, organic aldehydes and

\footnotetext{
${ }^{1}$ Petrosani University, 20, Universită t ii Str., 2675 Petrosani.

${ }^{2}$ Babeș-Bolyai University, 1 Kogă Iniceanu Str., Dept. of Geology, 3400 Cluj-Napoca.

E-mail:vcodrea@bioge.ubbcluj.ro
} 
acids). It is worth mentioning that the ash resulting from coal burning contains a series of toxic metals ( $\mathrm{As}, \mathrm{Cd}, \mathrm{Pb}, \mathrm{Mn}, \mathrm{Hg}, \mathrm{Ni}$ and $\mathrm{V}$ ) and radioactive elements. The pollutants resulting from burning fossil fuels affect not only the quality of the atmosphere but also that of the other biotic and abiotic environment factors thus directly or indirectly affecting people (Manahan, 1993).

\section{General considerations regarding TPP Paroșeni}

TPP is located on the right bank of the West Jiu Valley, on its lower terrace, along the Vulcan-Lupeni railway.

The need to build the power plant was felt in 1950, when the electricity consumption of the area could not be covered anylonger. In order to supply the energy required by the Metallurgy Centre Hunedoara (72 MW) and by the other users in the Jiu Valley ( $55 \mathrm{MW}$ ) the government took the decision to build this power plant. The first group was put into operation in 1956. In 1959, after the whole plant was put into operation, it reached the level of $150 \mathrm{MW}$.

Subsequently, in 1965, a 150 MW group was installed and the power plant became the largest one in the country at that time. Later, further changes were carried out at TPP, among which the putting into operation of a heat carrier generation and transfer plant (in 1984) and the installation of a new boiler (in 1989) with a rate of flow of $1,500 \mathrm{t} / \mathrm{h}$ and a heat supply of 103.2 $\mathrm{Gcal} / \mathrm{h}$. TPP uses the following categories of solid fuel:

energetic mixed bituminous coal

energetic slime

sometimes semi-coke, the supplier being $\mathrm{CNH}$ Petroșani.

Methane provided by ROMGAZ Medias is used as firing support.

Water for the TPP is caught from the West Jiu (there is a dam on this river), from the Baleia and Că prișoara streems. The cooling water is taken from the West Jiu Valley (which is caught by means of a dam built upstream of the TPP). The cooling water has a very high purity level and, therefore, it is much cleaner on discharge than the water in the Jiu River. There have, however, been accidental cases of pollution in the West Jiu Valley due to accidental discharges of the slag-ash mixture in cases of defects of the mixture transport pumps.

\section{Mineralogical and gochimical characteristics of the coal used at TPP Paroșeni}

There are 31 validated layers of coal in the Petrosani Basin. They are located as follows: 22 (from 0 to 21) at level 2 („lower productive level”), distributed in a more or less complete number in all mining fields; and 9 (from 22 to 30 ) at level 4 („,upper productive level”), distributed only in the Să lă truc mining field. The layers are numbered upwards, that is in the order of their depositing in the stratigraphic succession.

From a geological point of view, each of the 31 layers is characterized by certain specific features, such as: position in the sequence, thickness, geometry, extension, type of floor, type of roof, number of banks, type of coal, time of deposition, economic importance. 
Out of the three main maceral groups of bituminous coals - vitrinite, exinite and inertinite - the former is the most important one from the point of view of the properties of the northern hemisphere clay coals. It is the predominant group and carries the best caking and coking capacity. Bituminous coal vitrinite is produced by the carbonification of the brown coal huminite: each maceral subgroup of this huminite produces one type of vitrinite maceral characteristic for the bituminous coals with the lowest carbonification level - i.e., buckling bituminous coals. These are represented by bituminous coals of different ranks named: Aninoasa, Lupeni, Anina, Doman.

The vitrinite of the isometamorphic bituminous coals is the maceral group having the following intermediate chemo-structural features: the exinite has the highest level of volatile substances and the highest chemical fraction $\mathrm{H} / \mathrm{C}$, whereas the inertinite with the maximum carbon percentage has the lowest level of volatile substances and the lowest atomic fraction H/C. As far as the elementary composition is concerned (in gravimetric percentages), the inertinite contains relatively more carbon, the exinite more hydrogen and the vitrinite more oxygen.

Taking into account these chemical characteristics specific for maceral groups which are due to their origin as products of carbonification under various conditions as well as due to the different types of substances they originated from, we can explain the different chemical and technological properties of bituminous coals and the influence of the maceral composition upon the relationship between the vitrinite reflection capacity and the volatile substances in the coal. Thus, a high content of inertinite (over 30-40\%) considerably reduces the percentage of volatile substances of the respective bituminous coal if it is not counterbalanced by high percentages of exinite. Such high levels of inertinite can generally be found in coals of the gondwanian type (southern hemisphere) and the carbon-bearing bituminous coals of the northern hemisphere (European type) which often have an inertinite content of less than $15 \%$.

Bituminous coals have a very similar carbopetrographic composition with a higher proportion of exinitic clarain at Aninoasa and Bă rbă teni. This indicates the fact that they have the same originating substances and the same depositing conditions. The differences existing in their technological properties are especially due to the different degree of carbonification.

As a general characteristic of the Jiu Valley bituminous coals we should note the absence of classical petrographic compounds, such as the microlithes durain and fusain - which is mainly due to the lack of sufficient amounts of inertinite maceral (over 5\%). Therefore, we can state that these bituminous coals mainly consist of clarain and vitrain, two shaly minerals, which highly contribute to the structure formation by means of the microlithe carbo-mudstone.

The vitrain - a non-maceral microlithe - represents an average of 25$30 \%$ of the coal substance. Vitrinite is, however, the main and most representative maceral for the Jiu Valley coals $-77-82 \%$ vol. to the total coal - corresponding to $84-90 \%$ vol. to the organic mass. These values are relatively constant over time and gives these bituminous coals the characteristics of vitrinitic coals. It 
consists of over $62 \%$ collinite and desmocollinite (an incompletely vitrinised component) and $10-16 \%$ telinite (the vitrinite with a cellular or fibrous structure). The collinite which has a rather low capacity of reflection, appears to be greyish under reflected natural light. It can usually be found on extended beaches forming bands (telocollinite) or lenses (gelocollinite). It is frequently impure due to clayish mineral substances or to granular pyrite. The clarain, whether it is from resinite or from cuticles or spores, is more frequent than the microlithotype vitrain (an average of $48-50 \%$ of the coalsubstance). Since, however, there is a net preponderance of vitrinite (abt. $80 \%$ vitrinite in the coal sunstance), it is a vitrinitic clarain. This is also a characteristic of the Jiu Valley coals.

Another general characteristic feature, with high importance for the properties of the Jiu Valley coals, is the high proportion of desmocollinite (13$20 \%$ ) and telinite (over 10\%) as vitrinitic maceral specific of the low rank bituminous coals. (Panaitescu, 1991).

From the point of view of carbo-mineral carbomining associations and of the mineral substance, the Jiu Valley bituminous coals are characterised by high percentages of clayish minerals which are finely or grossly disseminated in vitrinite - carbo-mudstone - and by granular pyrite finely distributed or in nests - carbo-pyrite. The fine dispersion of clayish mineral substances and of granular pyrite in vitrinite limits the minimal content of ash and sulphur that can be obtained on the washing for coking.

Carbonates in the form of siderite or spar can be found in small amounts; the same is true about quartz, which is disseminated in organic substances.

It is important to know the petrographic composition of slags according to their component parts and degree of thermal transformation in order to control the quality of grinding, the process of burning and its efficiency. The possibility of using the slags is established depending on the content of combustible matter and waste and on their chemo-technical properties. The petrographic research carried out in this respect in 1973-1975 included the evaluation of the structural and quantitative composition of the coals used for burning and of the resulting slag. Chemo-technical analyses were added to these studies. The results showed the following:

- if the burning in the hearth is incomplete, slag represents a combustible material with a content of organic matter of $40-46 \%$ as to the dry mass; this slag could be used for a possible mixture for re-burning without important problems from the point of view of the combustion process;

- the slag combustible mass consists of raw coal material - which is degassed at different temperatures - and coke in various proportions depending on the burning process (e.g., 26:9:11\% vol., for the respective order)

- slag composition differs significantly according to the type of slag: floating slag and heavy slag. Floating slag, the quantity of which depends on the content of xyloidic components in the coal as well as on the waste humidity and its granulometry, contains a very high quantity of unburnt material (80-86\% vol.). Its main petrographic components are textinite and texto-ulminite. The total quantity of xyloidic components unaffected by burning is about $40 \%$, i.e., almost 120 
half of the combustible mass. The fine gelinitic material forms the rest of the organic mass together with semi-coke and coke. All these components float due to their form and specific weight (high porosity).

- heavy slags consist of about $49 \%$ organic material in different stages of degasification, coke included. The rest is unburnt mineral material, partially burnt material and slag. Due to this composition they differ from floating slags and they can be distinguished even macroscopically, due to their appearance and colour.

- the evaluation of the value of slag combustible mass by the chemical identification of ash causes errors due to the classical analysis methods with weight loss on clay, carbonate and sulphide decomposition. Therefore, it must be correlated with the results of petrographic analyses for waste type and content or it should be re-calculated according to different correction formulae.

From a petrographic point of view they can be divided into fly ash, slag from the burning plants, granules of unburnt or partially unburnt coal, ash spheres of various sizes such as coke and semi-coke and dust (in the thicker walls of certain ash spheres one can note an anisotropic mosaic structure); anisotropic nut coke - from vitrinite - or isotropic from various types of inertinite (low capacity of reflection, poor reactivity - honeycomb coke - and high capacity of reflection, with or without low porosity - unmelted coke); mineral material such as clay, pyrite, quartz, iron carbonates and oxides in various stages of thermal transformation. The chemical composition of the inorganic mass associated with the different petrographic compounds of the Jiu Valley coals is shown in Table 1. There are specific distributions of the different macerals and maceral groups according to the data from and the observation of the fine dissemination of clayish minerals and pyrite in collinite: $\mathrm{SiO}_{2}+\mathrm{Al}_{2} \mathrm{O}_{3}=41-67 \%$, $\mathrm{Fe}_{2} \mathrm{O}_{3}=37-41 \%$. This distribution suggests an important affinity of vitrinite for clayish minerals and for those having a significant iron content, but it obviously also depends on the structure and composition of the surrounding minerals and on the waters that have crossed the deposit. Carbo-mudstones, a microlithotype of quantitative and qualitative importance for the technological behaviour of the studied coals, has a characteristic mineral composition (fine or gross carbomudstone) with values ranging from those of vitrainite to those of clay shales. The carbo-mudstone of Coroiești and Lupeni has a high content of $\mathrm{SiO}_{2}(78-83 \%)$ in the form of finely agglomerate sediment or very fine free $\mathrm{SiO}_{2}$ granules.

Fine agglomerating sediment and very finely granulated free $\mathrm{SiO}_{2}$

Table 2 shows the average content of macroelements in the Jiu Valley coals.

As far as the quantitative distribution (in ppm) of inorganic microelements in petrographic components is concerned, we must note the borine accumulation in the vitrinite maceral with an inorganic mass rich in clayish substance. Their absorption especially by collinite is significant for its formation conditions. The high sulphur content of the Jiu Valley coals accounts for the presence of copper, especially in the compounds concentrating pyrite and probably associated with chalcopyrite. The values obtained for the other microcomponents show lower 
percentage associations of manganese and zinc with collinite and with the rest of the mineral mass. Nickel is found in vitrinite and molybdenum is associated with the clayish substance in the Lupeni coals (Table 3 ).

Table 1.

Chemical composition of the inorganic mass associated with the various petrographic components of the Jiu Valley coals (Panaitescu, 1991).

\begin{tabular}{|c|c|c|c|c|c|c|c|}
\hline \multicolumn{2}{|c|}{ Composition } & \multirow[b]{2}{*}{$\mathrm{SiO}_{2}$} & \multirow[b]{2}{*}{$\mathrm{Fe}_{2} \mathrm{O}_{3}$} & \multirow[b]{2}{*}{$\mathrm{Al}_{2} \mathrm{O}_{3}$} & \multirow[b]{2}{*}{$\mathrm{CaO}$} & \multirow[b]{2}{*}{$\mathrm{MgO}$} & \multirow[b]{2}{*}{$\mathrm{TiO}_{2}$} \\
\hline $\begin{array}{l}\text { Petrographic } \\
\text { component }\end{array}$ & Preparation & & & & & & \\
\hline Collinite & $\begin{array}{l}\text { Petrila } \\
\text { Coroieșt } \\
\text { Lupeni }\end{array}$ & $\begin{array}{l}35.2 \\
15.8 \\
21.9\end{array}$ & $\begin{array}{l}37.2 \\
25.6 \\
27.0\end{array}$ & $\begin{array}{l}24.7 \\
26.6 \\
27.3\end{array}$ & \begin{tabular}{|l|}
2.4 \\
24.6 \\
14.7
\end{tabular} & $\begin{array}{l}- \\
6.3 \\
8.8\end{array}$ & $\begin{array}{l}0.5 \\
1.1 \\
0.2\end{array}$ \\
\hline Telinite & \begin{tabular}{|l} 
Petrila \\
Coroiești
\end{tabular} & $\begin{array}{l}32.8 \\
23.2 \\
\end{array}$ & $\begin{array}{l}40.8 \\
6.4 \\
\end{array}$ & $\begin{array}{l}21.7 \\
44.3 \\
\end{array}$ & \begin{tabular}{|l|}
4.4 \\
22.5
\end{tabular} & - & \begin{tabular}{|l|}
0.3 \\
1.6 \\
\end{tabular} \\
\hline Inertinite & \begin{tabular}{|l|} 
Petrila \\
Coroiesti
\end{tabular} & $\begin{array}{l}351 \\
49.5\end{array}$ & $\begin{array}{l}1.8 \\
6.1\end{array}$ & $\begin{array}{l}43.9 \\
43.1\end{array}$ & \begin{tabular}{l|}
18.0 \\
1.2
\end{tabular} & $\begin{array}{l}0.9 \\
0.4\end{array}$ & $\begin{array}{l}0.9 \\
0.1\end{array}$ \\
\hline $\begin{array}{l}\text { Carbo- } \\
\text { mudstone }\end{array}$ & $\begin{array}{l}\text { Coroiești } \\
\text { Lupeni }\end{array}$ & $\begin{array}{l}82.7^{*} \\
8.1^{*}\end{array}$ & $\begin{array}{l}0.5 \\
9.4\end{array}$ & $\begin{array}{l}16.6 \\
10.9\end{array}$ & $\begin{array}{l}0.1 \\
0.4\end{array}$ & $\overline{-}$ & $\begin{array}{l}0.1 \\
0.1\end{array}$ \\
\hline Shale1 & Lupeni & 57.1 & 2.9 & 38.2 & 0.2 & 0.1 & 1.5 \\
\hline Shale 2 & Lupeni & 59.5 & 10.1 & 25.4 & 3.3 & 0.3 & 1.4 \\
\hline Pyrite & $\begin{array}{l}\text { Petrila } \\
\text { Lupeni }\end{array}$ & \begin{tabular}{|l|}
4.1 \\
18.7 \\
\end{tabular} & \begin{tabular}{|l|}
76.4 \\
56.8
\end{tabular} & \begin{tabular}{|l|}
3.2 \\
32.2 \\
\end{tabular} & $\begin{array}{l}10.8 \\
0.2 \\
\end{array}$ & $\begin{array}{l}5.4 \\
0.2 \\
\end{array}$ & $\begin{array}{l}0.1 \\
0.9\end{array}$ \\
\hline
\end{tabular}

Table 2.

Main elements in the Jiu Valley bituminous coals (Traistă , 1995)

\begin{tabular}{llllllllll}
\hline $\begin{array}{l}\text { Sample } \\
\text { place }\end{array}$ & $\begin{array}{l}\mathrm{SiO}_{2} \\
(\%)\end{array}$ & $\begin{array}{l}\mathrm{Fe}_{2} \mathrm{O}_{3} \\
(\%)\end{array}$ & $\begin{array}{l}\mathrm{Al}_{2} \mathrm{O}_{3} \\
(\%)\end{array}$ & $\begin{array}{l}\mathrm{TiO}_{2} \\
(\%)\end{array}$ & $\begin{array}{l}\mathrm{CaO} \\
(\%)\end{array}$ & $\begin{array}{l}\mathrm{MgO} \\
(\%)\end{array}$ & $\begin{array}{l}\mathrm{SO}_{3} \\
(\%)\end{array}$ & $\begin{array}{l}\mathrm{Na}_{2} \mathrm{O} \\
(\%)\end{array}$ & $\begin{array}{l}\mathrm{K}_{2} \mathrm{O} \\
(\%)\end{array}$ \\
\hline Lonea & 49.43 & 10.25 & 23.23 & 0.57 & 7.48 & 2.28 & 2.59 & 2.42 & 0.87 \\
Petrila & 52.59 & 10.51 & 18.86 & 0.78 & 6.60 & 2.69 & 2.35 & 2.97 & 0.73 \\
Petrila Sud & 51.80 & 10.05 & 22.89 & 0.85 & 5.61 & 2.35 & 3.09 & 2.85 & 0.62 \\
Dâlja & 55.60 & 8.05 & 23.70 & 0.87 & 6.78 & 1.34 & 2.43 & 0.93 & 0.27 \\
Livezeni & 53.26 & 8.31 & 25.69 & 1.04 & 4.44 & 2.20 & 2.30 & 2.10 & 0.53 \\
Aninoasa & 53.38 & 8.65 & 20.47 & 0.83 & 3.27 & 1.34 & 3.22 & 2.84 & 0.93 \\
Vulcan & 53.69 & 9.78 & 20.54 & 0.71 & 7.48 & 1.35 & 2.65 & 2.76 & 0.75 \\
Paroșeni & 51.69 & 7.75 & 19.29 & 0.92 & 7.71 & 1.35 & 3.39 & 2.94 & 0.84 \\
Lupeni & 53.91 & 8.31 & 25.69 & 0.83 & 4.44 & 2.02 & 2.24 & 1.67 & 0.45 \\
Bă rbă teni & 49.81 & 8.05 & 23.70 & 0.83 & 6.78 & 1.34 & 2.34 & 2.76 & 0.93 \\
Uricani & 52.78 & 12.84 & 17.20 & 0.82 & 5.14 & 1.85 & 2.77 & 2.93 & 0.87 \\
Valea de & 52.85 & 9.98 & 21.02 & 0.78 & 3.74 & 2.18 & 2.64 & 2.86 & 0.95 \\
Brazi & & & & & & & & & \\
Câmpu lui & 53.53 & 8.58 & 18.77 & 0.74 & 6.54 & 2.18 & 2.16 & 2.95 & 0.88 \\
Neag & & & & & & & & & \\
\hline
\end{tabular}

In thermoelectric power plants coals burn in the form of finely ground powders in a gas current blown in by injectors. The resulting ash is blown with the roast gases and is then captured in a gas cleaning system. The gross 122 
fractions (max. 20\%) are deposited in the lower part of the boiler. They can be agglomerated by partial melting in the form of slag with sizes ranging between 3 and $100 \mathrm{~mm}$ - furnace slag. The fine part is deposited in the centrifugal separators.

Table 3.

Microelements in the Jiu Valley coals (Traistă , 1996)

\begin{tabular}{lllllllllllll}
\hline Sample & $\mathrm{Ga}$ & $\mathrm{In}$ & $\mathrm{Mo}$ & $\mathrm{Ni}$ & $\mathrm{Sn}$ & $\mathrm{V}$ & $\mathrm{Cu}$ & $\mathrm{Pb}$ & $\mathrm{Zn}$ & $\mathrm{Cd}$ & $\mathrm{Cr}$ & $\mathrm{Mn}$ \\
place & $\mathrm{ppm}$ & $\mathrm{ppm}$ & $\mathrm{ppm}$ & $\mathrm{ppm}$ & $\mathrm{ppm}$ & $\mathrm{ppm}$ & $\mathrm{ppm}$ & $\mathrm{ppm}$ & $\mathrm{ppm}$ & $\mathrm{ppm}$ & $\mathrm{ppm}$ & $\mathrm{ppm}$ \\
\hline Lonea & 22 & 3 & 22 & 300 & 0 & 75 & 100 & 78 & 200 & 500 & 230 & 900 \\
Petrila & 10 & 1 & 20 & 260 & 6 & 75 & 400 & 29 & 150 & 380 & 200 & 800 \\
Petrila Sud & 14 & 2 & 9 & 180 & 0 & 75 & 600 & 34 & 135 & 300 & 200 & 600 \\
Dâlja & 15 & 3 & 13 & 290 & 0 & 75 & 400 & 60 & 200 & 400 & 200 & 860 \\
Livezeni & 40 & 2 & 0 & 240 & 7 & 100 & 600 & 50 & 170 & 420 & 200 & 850 \\
Aninoasa & 34 & 1 & 14 & 320 & 8 & 100 & 400 & 90 & 320 & 320 & 280 & 620 \\
Vulcan & 21 & 4 & 0 & 390 & 0 & 130 & 600 & 60 & 340 & 800 & 550 & 900 \\
Paroșeni & 19 & 1 & 0 & 250 & 0 & 95 & 240 & 34 & 170 & 320 & 200 & 950 \\
Lupeni & 12 & 0 & 0 & 200 & 0 & 65 & 180 & 35 & 200 & 280 & 160 & 850 \\
Bă rbă teni & 21 & 1 & 0 & 300 & 0 & 75 & 400 & 34 & 170 & 300 & 140 & 550 \\
Uricani & 28 & 2 & 0 & 400 & 7 & 110 & 400 & 50 & 220 & 300 & 225 & 650 \\
Valea de & 15 & 1 & 0 & 240 & 0 & 65 & 100 & 29 & 200 & 280 & 190 & 850 \\
Brazi & & & & & & & & & & & & \\
Câmpu lui & 10 & 2 & 0 & 170 & 0 & 36 & 100 & 34 & 160 & 200 & 140 & 650 \\
Neag & & & & & & & & & & & & \\
\hline
\end{tabular}

Like other solid fuels, the Jiu Valley energetic bituminous coals contain not only carbon but also a series of other elements, such as $\mathrm{H}, \mathrm{O}, \mathrm{N}, \mathrm{S}$, humidity and ash. If these mass fractions are added up, the combustible mass unit is obtained. During the burning process $\mathrm{C}, \mathrm{H}, \mathrm{O}, \mathrm{N}$ and $\mathrm{S}$ are transformed into volatile products whereas the humidity and ash represent the so-called fuel ballast because they affect the burning process if present in high proportions.

The most important groups of noxious substances released as a result of coal burning are $\mathrm{CO}$, carbohydrates, $\mathrm{NO}_{\mathrm{x}}, \mathrm{SO}_{\mathrm{x}}$.

The aim of the present paper is that of pointing out the toxicity of the noxious substances produced by the burning of Jiu Valley energetic bituminous coals in thermoelectric power stations.

\section{Release of pollutants from the chimney into the air}

The source of air pollutants is represented by the noxious substances from the roast gases resulting from the combustion in the boiler hearthes, namely: $\mathrm{CO}_{2} \mathrm{NO}_{\mathrm{x}}, \mathrm{SO}_{2}, \mathrm{CO}$ and dust. At the Paroseni TPP roast gases are exhausted through a chimnei with $\mathrm{h}=120 \mathrm{~m}$ and top $\Phi=6.0 \mathrm{~m}$.

The following roast gas volume and concentrations of released pollutants were established for one year:

$\mathrm{V} \times 10^{3} \mathrm{Nm}^{3}=9160175$

concentration of $\mathrm{SO}_{2} \mathrm{mg} / \mathrm{Nm}^{3}=1592.55$

concentration of $\mathrm{NO}_{x} \mathrm{mg} / \mathrm{Nm}^{3}=296.0$ 
These concentrations were calculated by the ratio of the yearly quantity of pollutant (in $\mathrm{mg}$ ) and the volume of wet roast gases exhausted through the chimney $\mathrm{V}$ under normal conditions $\left(0^{\circ} \mathrm{C}\right.$ and $\left.760 \mathrm{~mm} \mathrm{Hg}\right)$ with an oxygen content of $6 \%$ in the roast gases.

Since these toxic gases are simultaneously present in the atmosphere around the chimneys of power stations using solid fuel, a synergetic additive effect can be noted. Risk assessment is performed taking into account their combined effect. It is considered that the synergetic additive effect occurs in the case of toxic substances the aggressivity target of which is the same body organ or system or when the toxic substances have the same action mechanism.

\section{Concentration values of released pollutants}

According to the MAPPM regulations and to the order no. 462/93, the following norms apply for TPP Paroșeni depending on the consumption of each fuel:

for $\mathrm{NO}_{\mathrm{x}}$ - from 500 to $800 \mathrm{mg} / \mathrm{Nm}^{3}$ gases with $6 \% \mathrm{O}_{2}$;

for particles from 75 to $150 \mathrm{mg} / \mathrm{Nm}^{3}$ gases with $6 \% \mathrm{O}_{2}$; following:

The analysis of gases exhausted through the chimney showed the

thermal duty $-48.60 \%$

content of $\mathrm{O}_{2}$ in the chimney gases - $16.45 \%$

content of $\mathrm{CO}_{2}$ in the chimney gases $-4.00 \%$

air excess in the chimney -4.51

gas temperature $-80.1^{\circ} \mathrm{C}$

nox concentration in wet gases $-300.0 \mathrm{mg} / \mathrm{Nm}^{3}$

$\mathrm{SO}_{2}$ concentration in wet gases $-1402 \mathrm{mg} / \mathrm{Nm}^{3}$

It is obvious that the norms are not surpassed for $\mathrm{NO}_{\mathrm{x}}$ and $\mathrm{SO}_{2}$, whereas the norms are surpassed in the case of particles.

In Romania air pollution is regulated by STAS 12574/87 drawn up by the Ministry of Health Care. According to this STAS, the air quality is defined depending on the Maximally Admitted Concentrations (MAC) of various pollutants. The values obtained for TPS Paroșeni are shown in Table 4.

Table 4.

Yearly and daily average values of MAC and maximum values calculated at TPP Paroșeni.

\begin{tabular}{|l|l|l|l|}
\hline \multicolumn{1}{|c|}{ Interval } & \multicolumn{1}{c|}{$\begin{array}{c}\text { Noxious } \\
\text { substance }\end{array}$} & \multicolumn{1}{c|}{$\begin{array}{c}\mathrm{MAC} \\
\mu \mathrm{g} / \mathrm{Nm}^{3}\end{array}$} & \multicolumn{1}{c|}{$\begin{array}{c}\text { Maximum calculated value } \\
\mu \mathrm{g} / \mathrm{Nm}^{3}\end{array}$} \\
\hline $\begin{array}{l}\text { Daily average } \\
\text { Yearly average }\end{array}$ & $\mathrm{SO}_{2}$ & $\begin{array}{l}250 \\
60\end{array}$ & $\begin{array}{l}246 \\
41.51\end{array}$ \\
\hline Daily average & $\mathrm{NO}_{2}$ & 100 & 22 \\
Yearly average & 40 & 36.9 \\
\hline Daily average & Powders & 150 & 800 \\
Yearly average & 75 & 130 \\
\hline
\end{tabular}




\section{Dispersion of Pollutants in the Atmosphere}

The weather conditions in the Jiu Valley have a major influence on pollutant spreading in the Jiu Valley. Its long basin form, surrounded by mountains, has a great influence upon the climate since air mass circulation is easier along the Cerna-Jiu Valley (the longitudinal cleavage of the Southern Carpathians) and to a lower extent in the north-south direction along the transversal breaches Banit a - Merișor and Surduc - Lainici. The mountains limit the circulation of air masses and they also prevent air refreshing.

The orographic conditions influence the characteristic features of air currents. Air circulation from the west and northwest predominates in the western part of the country but the Retezat and Godeanu Mountains act as brakes and cause a local deviation of the currents. Therefore, in the Petroșani area the north-south circulation along the transversal Carpathian cleavage predominates. However, although western winds do not predominate, they are the strongest. In wintertime there are frequent sedimentations of cold air at the bottom of the depression, which bring about long calm periods. The months of December and January include $82-83 \%$ calm periods. A local characteristic is also the wind blowing from the Jiu cleavage, which is strong and cold especially in winter and spring. Winds from the northwest with a lot of humidity predominate in summertime. The southern winds are the most unpleasant because they cause falls in temperature in winter and spring and droughts in summer.

The circulation of air currents along the main valleys (Taia and Jiej) is a frequent phenomenon, which occurs when there is no general movement. The predominant wind circulation is shown in Fig. 1.

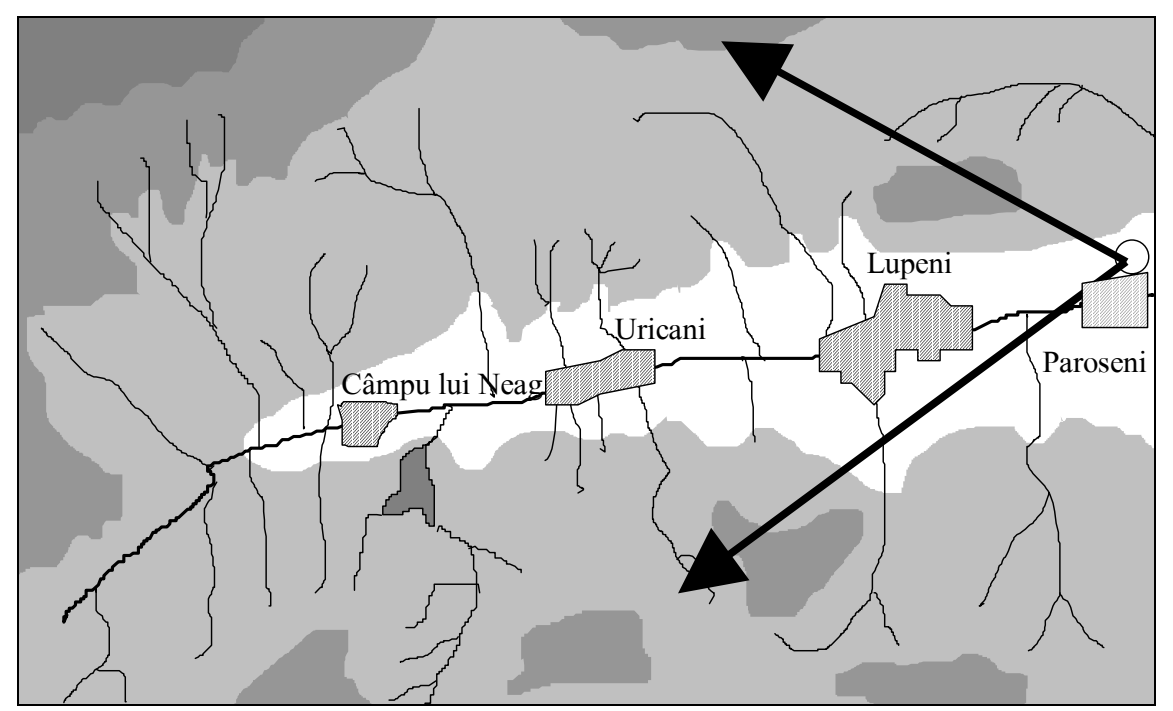

Figure 1. Relief and main directions of the air circulation in the Jiu Valley

The release of aerosols is specific for industrial plants using solid and liquid fuels (thermoelectric power stations, housing, thermal power stations, transportation, etc.). These particles are deposited on tree leaves where they 
temporarily accumulate. Due to rainfall, they are washed away and transported to the soil where they accumulate permanently. The average monthly accumulation of powders in the close neighborhood of the TPP Paroșeni amounts to $25.7 \mathrm{~g} / \mathrm{m}^{2}$. This means that the quantity deposited over the 40 years since the power station works is $12.3 \mathrm{~kg}$ of dust per $\mathrm{m}^{2}$ (forming a layer of $0.7 \mathrm{~cm}$ ). This enormous quantity of dust affects soil quality. The sediment particles deposited in the western Jiu Valley soil are shown in Fig. 2.
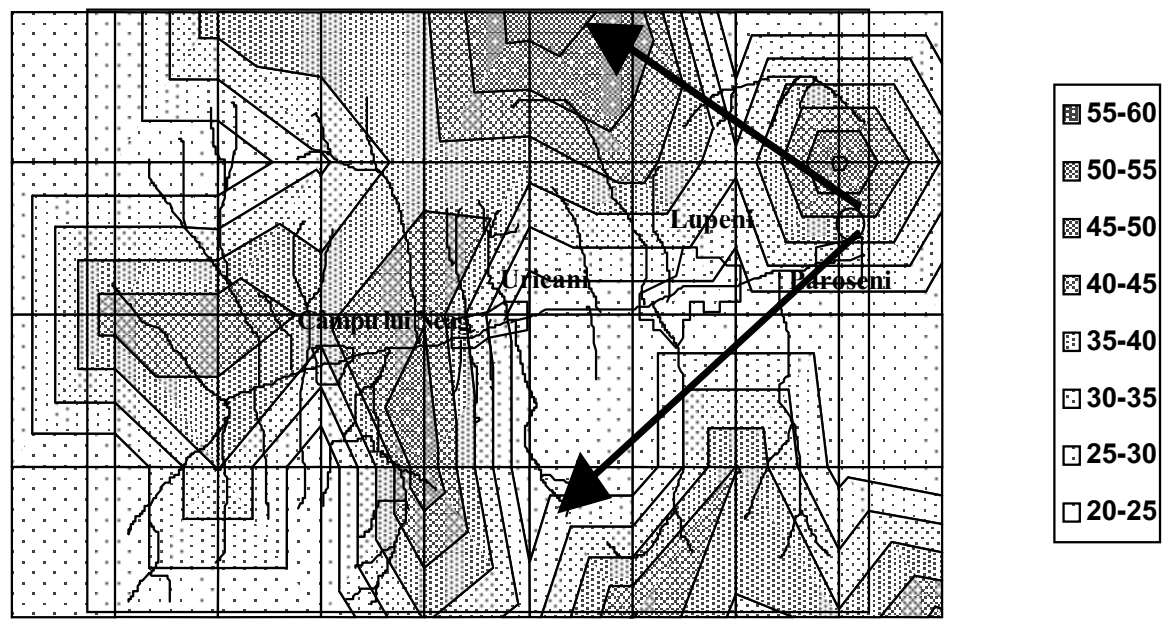

Figure 2. Dust content in the western Jiu Valley soil.

\section{Conclusions}

The maximum value of the average yearly concentration of suspension powders is $4.3 \mu \mathrm{g} / \mathrm{m}^{3}$, whereas the same value over 30 minutes is $49.3 \mu \mathrm{g} / \mathrm{m}^{3}$.

According to the dispersion maps, the maximum pollutant concentration (powders) can be found in the source epicentrum; it decreases with distance and becomes negligible $10 \mathrm{~km}$ away from the source. This conclusion applies to the dispersion of other noxious substances, such as $\mathrm{NO}_{2}, \mathrm{SO}_{2}, \mathrm{CO}$ and $\mathrm{CO}_{2}$.

Pollutants resulting from fossil fuel combustion deteriorate not only the atmosphere quality but also that of other biotic and abiotic environmental factors, thus directly or indirectly affecting the population.

\section{REFERENCES}

Manahan, E. S. (1993) : Environmental Chemistry, Lewis Publishers, Chelsea.

Panaitescu C. (1991): Petrografia că rbunilor, cocsurilor și produselor carbonice, Editura Enciclopedică , București.

Traistă E. (1995): Compoziț ia chimică a cenușii că rbunilor de Valea Jiului, Conț inutul de macroelemente, Contract de cercetare.

Traistă E. (1996): Compoziț ia chimică a cenușii că rbunilor de Valea Jiului, Conț inutul de microelemente, Contract de cercetare.

${ }^{* * *}$ Enciclopedia de chimie, vol.2, Ed. Enciclopedică , Bucuresti, 1966. 